\title{
Evaluation of Health Examiners Training Programs for Pilgrim Candidates at the Puskesmas Level in Bapelkes Cikarang
}

\author{
Lukman Ruskanda, Zulfiati Syahrial, Atwi Suparman
}

\begin{abstract}
This objective of this study was to determine the effectiveness of the implementation of the Education and Training Medical Examiner Officer Hajj (PPKJH). The study used the evaluation method and model 4-L of Kirkpatrick. The instrument used in this study were interviews, observation, study documents, and questionnaires. The study was conducted at the National Bapelkes Cikarang. The study concluded that: (a) the implementation of the Health Inspector Training Officer Hajj (PPKJH) in Cikarang Bapelkes already well underway; (b) the evaluation of the reaction to the training activities. Based on the reactions or responses of participants on the implementation of training programs conducted for 6 days in accordance with the amount of material (eye training) provided, (c) evaluation of learning outcomes (learning) is sufficient, mastery of cognitive already high enough on the exam I and II, where participants will be able to exceed the limits of at least $75 \%$ mastery of the material, (d) the evaluation of work behavior (behavior) in the form of appliance of learning outcomes and the changes brought about are in good category, this means the use of science obtained almost entirely implemented, (e) evaluation of the impact which Training PPKJH against the unit of work which includes products, such as inspection administrative tools, show improvement, more complete and qualified. Similarly, the management techniques Jemaah pilgrim health checks, are in both categories. (f) the evaluation of work behavior (behavior) in the form of appliance of learning outcomes and the changes brought about are in good category, this means the use of knowledge gained almost implemented entirely.
\end{abstract}

Index Terms: Program evaluation, Kirkpatrick Model, education and training

\section{INTRODUCTION}

The health status of the support for the pilgrims who will perform the Haji is a major concern for the haji organizing institutions. In connection with that, the organizers of the Haji is obliged to carry out development, service, and proper protection by providing the necessary facilities and ease of assembly of pilgrims. The effort began by training inspectors pilgrim pilgrims gradually and continuously. The training is always quality improvement effort to the improvement of curricula and training modules. Furthermore, the curriculum and the modules are arranged is then implemented into a learning process in Haji training organized jointly by the Ministry of Health, especially through the Education and Training Center for Health Human Resources together with

Revised Manuscript Received on September 22, 2019.

Lukman Ruskanda, Balai Latihan Kerja Kesehatan Jakarta lukman.ruskanda@gmail.com.

Zulfiati Syahrial, Profesor at Universitas Negeri Jakarta

Atwi Suparman, Profesor at Universitas Terbuka Jakarta. the relevant parties. Actual implementation of the system health checks Jemaah Haji Candidate (JCH) are set out in detail in the book JCH implementation guidelines for medical examination, however, in practice in the field implementation of health checks vary greatly. It is influenced by the competence of human resources, local government policy, especially in terms of funding / infrastructure costs and availability checks.

Observing that the above and is driven by the need for standardization of inspection urgent, then counter posed policies through initiation and basic interventions for health inspectors for $\mathrm{JCH}$, such as training health inspectors $\mathrm{JCH}$. The training is intended to promote the ability of HR officers in achieving standardization efforts controlling implementation JCH health in various knot.

\section{LITERATURE REVIEW}

Education and training is a process of activities to obtain more qualified employees and have a good mental attitude, honest behavior, discipline and devotion, so as to improve services and protection to the public as well as possible. This is in line with the views expressed by Detyna, Detyna, and Kajewska which states that medical personnel both doctors and nurses aware of the need for professional development that will trigger their welfare in the role of his organization (Detyna, Beata, Detyna, Jerzy, Dudek-Kajewska, 2016).

To guarantee the implementation of Hajj Pilgrimage education and training, then do the evaluation to see penyelengaraannya effectiveness. But in fact, the evaluation is rarely done by organizing training institutions including the National Institute of Administration as Guiding Authority Training Institute of the Ministry of Health. Training Centers (Bapelkes Cikarang) Cikarang as education and training providers in the health ministry, the need to conduct evaluation activities as a form of public accountability (accountability function) to stakeholders and service improvement plans to the user (user). As quoted by Stufflebeam that evaluation is a process illustrates, In particular the evaluation of the program in government institutions and education is a process to ensure accountability and continuous improvement of quality of education and training should be seen as a whole against all stages from preparation, implementation, until the results of the assessment and the impact of training on productivity improvement or performance of the service of an institution (Daniel L. Stufflebeam \& Anthony J. Shinkfield, 1981). 
Training should be a solution of personnel competency gaps. Participation of attendees, the range of material and its delivery models as well as technical implementation is designed as a reflection of the culture of adult education which also combines the establishment of discipline, academic and administrative capacity in a collegial atmosphere. Participant recruitment system based on the needs of the organization, the reason for the increase in performance, capability and skills of employees, rank, and so on (Thoha, 2005).

Based on the description above, the researchers felt the need to evaluate the education and training program of the Hajj pilgrims health examiners at this training program at Bapelkes Cikarang. The focus is to see this training objectives and the impact, taking into account the performance and impact on the workplace of the participants, with reference to Kirkpatrik models. Sub focus of research are: (1) Reaction, which is how the participants in the program that followed; (2) Learning peeling the material studied and the results are expected as well as the type and quality of the tests used; (3) Behavior, which is how the application of the results of training (learning outcomes) and; (4) Result, namely how the impact of training on workplace participants. In general, the Program Evaluation Research aims to determine with certainty of achievement, progress and obstacles encountered in the implementation of programs/ activities (Gall, Gall, and Borg, 2003: 542). The results obtained will be assessed and studied for the improvement of the implementation of programs/ activities in the future.

The fourth stage of the evaluation should be carried out simultaneously, step by step to maintain the consistency of the results of the evaluation are expected (Crone, 2005). The fourth stage is as follows: Evaluation Reactions come into one's vision-right phase of the study to measure the effectiveness of training programs based on the reaction or response of participants on the implementation of the training program followed. Reaction evaluation aims to get feedback and comments of participants of the training program based on participant satisfaction with the services of the organizers, Lecturer (sources), and the facilities they receive (Kirzpatrick, 2005). There are several reasons why the measurement of the reaction is an important participant , namely: (1) provide feedback and help to develop the program in the future, based on the evaluation, comments, and suggestions from the participants; (2) help lecturer to improve its performance, after obtaining correction and input from participants; (3) The reaction provide valid information to be given to the person in charge of programs and institutions associated with the implementation of Pre-service training; and (4) reaction participants can provide valid data and can be used to develop standards of performance trainers in the future (Kirzpatrick, 2005). Evaluation Behavior is a step for measuring application of knowledge and training outcomes and their effects on behavior change participants work. Positive changes that occur at this stage, to determine the success of stage effects (Result) against workplace alumni, therefore, very important to know whether the knowledge, skills and attitudes learned in training activities have been implemented alumni job. There are a few things to note at this stage that these activities are done after the training is complete and participants have been working again for some time in the workplace.

Impact Evaluation (Result) of the unit can be defined as the end product of the influence of education and training to work, how much productivity can be improved after the alumni can apply knowledge and skills acquired during the training. Changes in work behavior expected positive impact on the workplace. In this case because the participant is a health examiner for the Hajj congregation, then how does the education and training impact on the improvement of the service process and the quality of the device and the supporting media of the service it produces. In other words, the impact of training is the result of changes in work behavior after participants apply the knowledge gained in the training.

In general, this evaluation research aims to determine the organizing success of the training of hajj pilgrims health examiners officer. Operationally this evaluation research activity has a purpose: (1) how the effectiveness of the training activities related to the components of learning activities that include: a) The material must be given; b) The timeliness of learning the characteristics of learning materials; c) the level of compatibility and use of material in the workplace of participants; d) Widyaiswara display; and e). the suitability of the number and competence Widyaiswara with training eye to be taught in Bapelkes; (2) how the effectiveness of this training activity is related to the components of learning facilities, namely a. feasibility study room, library, computer lab; b. the availability of teaching materials/ modules; and c. the availability of teaching aids in Bapelkes; (3) how about the Diklat curriculum towards the accuracy of training objectives and objectives; (4) what is the level of mastery of training participants' material; (5) how the application of learning outcomes and changes in education and training to work behavior, knowledge and skills of alumni are applied; (6) how the impact of this training on the alumni workplace includes: a) loyalty and perception of work; and b) initiatives; (7) how the impact of education and training on the workplace of alumni includes a) the products produced, and b) the ability to cooperate in teams (supervisors and coworkers); (8) how this training program has good value (merit), usability (worth), interest (significance) and honesty (probity).

\section{METHODOLOGY/MATERIALS}

This research was conducted with an qualitative approach where empirical data from each aspect of the components were evaluated compared to the criteria/ standards that had been determined. The implementation of education and training evaluations was conducted at Bapelkes Cikarang and Karawang District Health Office, February to October 2017.

The evaluation method determines research techniques to be used, the type of data to be collected, the instrument will be used to collect the data and how the data collection and analysis techniques.

\section{Published By:}


The method to be used is a evaluative method. Evaluative Methods according Sugiyono is a research method that is based on the philosophy postposivitisme, is used to examine the condition of the object that is natural, triangulation (combined), data analysis is inductive/ qualitative, and the results further emphasize the significance of the generalization (Sugiyono, 2012).

Evaluation model used is a model Kirkpatrick. This model is made up of four types of evaluation which is a series of activities. These four types of evaluation have different object of study. Stages of activities to be undertaken are: (1) determine the aspects and evaluation criteria; (2) develop instruments that will be used; (3) collect data; (4) perform data analysis; (5) prepare the results of the analysis; (6) formulate conclusions based on the overall results of the evaluation; and (7) make a recommendation.

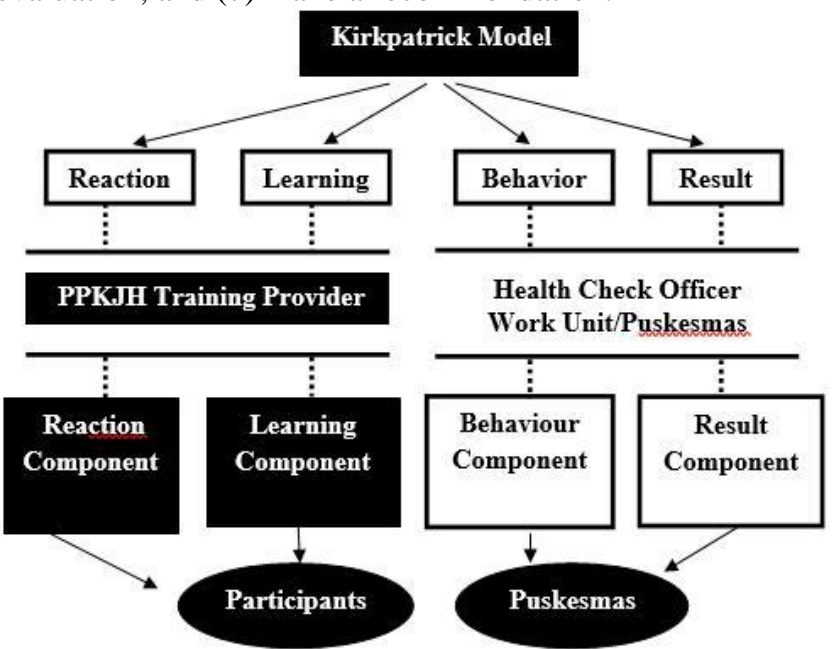

Fig 1:-Diagram of The Evaluation Design Training PPKJH Kirkpatrick Model

The main instruments that will be used to collect data were questionnaires and interviews. Gall as the opinion that to collect data on phenomena that can not be directly observed such life experiences, opinions, values and the like are better used questionnaires and interviews (Gall, Meredith, Joyce P. Gall, and Borg, 2007). Questionnaires and interviews can also be used to direct data from observable phenomena, but with the variety of considerations will be more easily done through questionnaires and interviews.

Evaluation instruments in this evaluation study include: (a) guidelines for assessment documentation; (b) guidelines for the interview; (c) the evaluation sheet; and (d) test the ability of the training program participants. Validation of evaluation instruments carried by 2 lecturers and 1 head section training and education programs. All three served in the Ministry of Health Training Center and was involved in the preparation of curricula, modules, speakers, and evaluating training organized by the Ministry of Health.

Collection techniques in the evaluation of programs tailored to the component data sought by using questionnaires, interviews, inventory check list and observation form and document study, a panel discussion and analysis of test results. Summary of data collection techniques are presented in Table 1.
Table 1:-Summary of Research Data Collection Techniques

\begin{tabular}{|c|c|c|}
\hline Component & Focus & Data Collection \\
\hline Evaluation & & Technique \\
\hline \multirow[t]{2}{*}{ Reaction } & $\begin{array}{l}\text { 1. Learning } \\
\text { components }\end{array}$ & $\begin{array}{l}\text { Questionnaire, } \\
\text { interview }\end{array}$ \\
\hline & 2. Learning facilities & $\begin{array}{l}\text { Inventory check } \\
\text { list }\end{array}$ \\
\hline \multirow[t]{3}{*}{ Learning } & $\begin{array}{l}\text { 1. Training and } \\
\text { learning } \\
\text { objectives }\end{array}$ & $\begin{array}{l}\text { The study of } \\
\text { documents, } \\
\text { discussion }\end{array}$ \\
\hline & 2. Item Test & $\begin{array}{l}\text { Studies } \\
\text { documents, test } \\
\text { analysis }\end{array}$ \\
\hline & $\begin{array}{l}\text { 3. The Level of } \\
\text { mastery of the } \\
\text { material }\end{array}$ & $\begin{array}{l}\text { Analysis of the test } \\
\text { results }\end{array}$ \\
\hline \multirow[t]{3}{*}{ Behavior } & 1. Implementation & Questionnaire \\
\hline & $\begin{array}{l}\text { 2. Aspects of } \\
\text { cooperation }\end{array}$ & Questionnaire \\
\hline & 3. Aspects of behavior & Questionnaire \\
\hline \multirow[t]{2}{*}{ Result } & 1. Product produced & Questionnaire \\
\hline & $\begin{array}{l}\text { 2. Display in the } \\
\text { examination room }\end{array}$ & Observation \\
\hline
\end{tabular}

Analysis of the data used in this research is descriptive statistical analysis with frequency distribution and analyzed qualitative analysis through data reduction, data presentation, drawing conclusions, verification, and interpretation of data.

\section{RESULTS AND FINDINGS}

Training participants are Civil Servants who come from the Karawang District Health Office consisting of doctors, laboratory officers, and nurses who serve in the Puskesmas as the Hajj Pilgrims Health Check Team that will perform the Hajj. Training participants numbered 30 people with a composition of 10 general practitioners, 10 nurses, and 10 laboratory officers.

\section{A. Evaluation Reaction}

Evaluation of reaction is a measurement of the satisfaction of training participants to the training activities followed. The participants' reactions determine the level of effectiveness of education and training undertaken. In other words, to see how the participants gave an assessment of the education and training through a questionnaire given and interviews.

The effectiveness of the training program at Bapelkes Cikarang, based on evaluation of reaction or response of participants on the implementation of the training program with an open interview techniques and giving a questionnaire consisting of 24 items using the Likert Scale questions. The focus of the evaluation phase is the reaction of the learning activities that include: (a) the duration and timing components of learning; (b) the flow of materials to the needs of participants in the workplace; (d) the performance of lecturer; and (d) the completeness of facilities and infrastructure of learning. 


\section{1) Reactions to the Duration and Time to Learn}

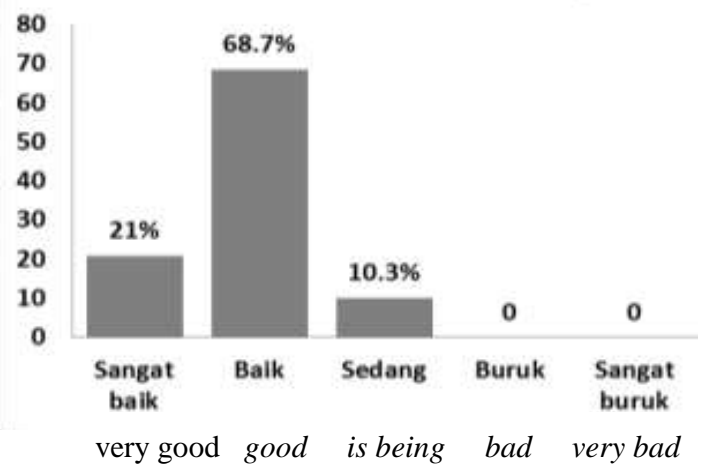

Fig 2:-The Reaction of Participants to The Duration of The Training and Learning Time.

Based on Figure 2 shows that $21 \%$ of participants stating the duration and time to learn very well, $68.7 \%$ of the participants stated either. This is also reinforced by the comments written on the questionnaire participants were given. Participants stated that the period of 6 days allowing it to explore a given training eye, so they believe is adequate time for the material provided. However, there are $10.3 \%$ of the participants responded to a range of training and learning time in the medium category, because they consider need more time in studying the materials provided, while the schedule was too forced and too dense.

\section{2) The Reaction to the Material Needs of the Participants.}

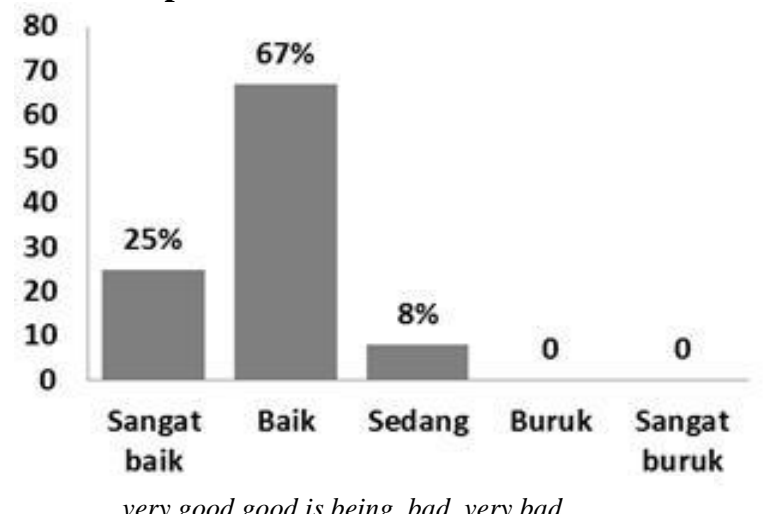

Fig 3:-The Reaction of Participants to Match Training Materials.

Based on Figure 3 shows that for the reaction of participants to the components associated with the flow of materials to the needs of the participants as the Labor Inspector of Health Jemaah Candidate Haji, 8\% of respondents were (fairly), 67\% responded well and $25 \%$ answered already very good, although there is material presented relating to substances such as anti-corruption training are not so relevant for health checks pilgrims no government budget is used.

\section{3) The Reaction to Widyaiswara Performance}

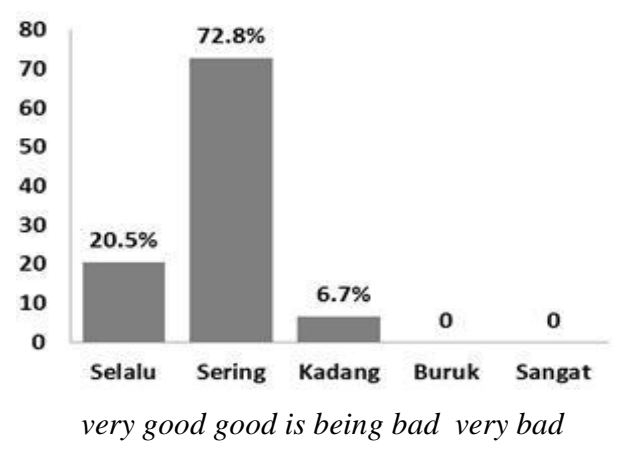

Fig 4:-The Reaction of Widyaiswara Performance.

Based on Figure 4 shows that the response or reaction of the participants of the performance of lecturers such as mastery of materials, methods of teaching and learning media and achievement of learning goals $20.5 \%$ of participants (respondents) stated performance is very good lecturers, $72.8 \%$ of respondents answered either and only $6.7 \%$ said medium. Performance trainers in the excellent category and can be used as an example of the learning model and the management of a good overhaul, such as how to do a good discussion, how to use the facilities and infrastructure both in the investigation and provide good extension to the pilgrims Candidate to provide understanding of the importance of health during the running of worship pilgrimage. The following chart performance feedback lecturers.

\section{4) The Reaction to The Training Facilities and Infrastructure}

The responses or reactions of participants to education and training facilities in general stated very well. This is because the facilities and infrastructure of the training at Bapelkes Cikarang are indeed good. The following graph.

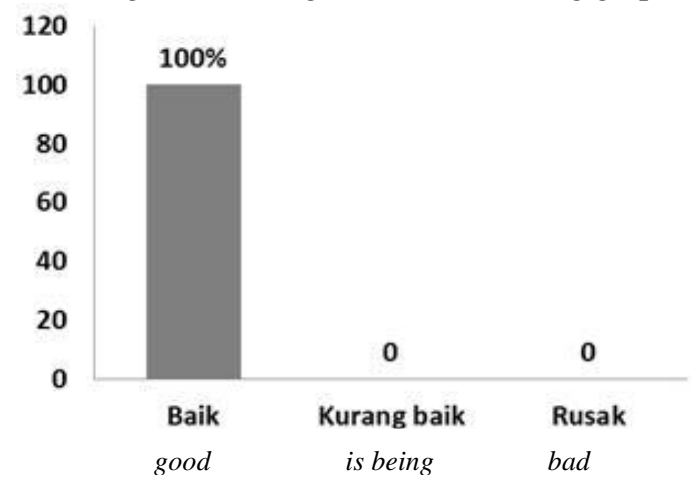

Fig 5: The Reaction of Participants to Facilities and Infrastructure.

\section{B. Evaluation of knowledge (learning)}

At this stage the evaluator examines what knowledge is gained by the training participants in learning, which includes the skills, attitudes and behaviors and expected learning outcomes of the learning. This is important, because the success of the next stage, namely the stage of work behavior (behavior) and the stage of impact (result) does not occur if the learning objectives are not achieved optimally. Then an assessment of the feasibility of the syllabus, curriculum and questions was used in the exam. From the research results obtained data, that in the Hajj Health Examination Officer training program there were 8 training courses taught and supplemented with material of

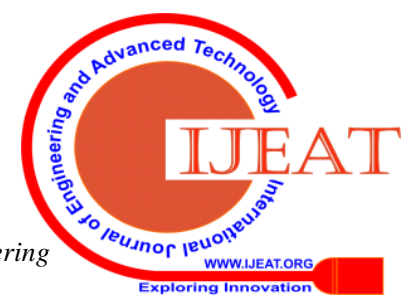


Building Learning Commitment and Follow Up Plan, with the following data:

Table 2:- Training Materials for Hajj Pilgrims Health Examiners

\begin{tabular}{clc}
\hline Number & Training Eyes & $\begin{array}{c}\text { Lesson } \\
\text { Hours }\end{array}$ \\
\hline 1 & Hajj health training policy & 2 \\
2 & Hajj health check policy & 2 \\
3 & Health checks pilgrims & 8 \\
4 & Health care and maintenance of & 5 \\
& pilgrims & \\
5 & Recording and reporting of health & 6 \\
& examinations for pilgrims at & \\
$\quad$ Puskesmas and Hospitals & 4 \\
6 & Protection and control of health risk & \\
7 & factors for individual pilgrims & 9 \\
8 & Health care for pilgrims & 2 \\
9 & Building Learning Commitment & 2 \\
10 & Follow up plan & 2 \\
\hline Total Number of Hours: & 42 \\
\hline
\end{tabular}

To test the ability of training participants in mastering the material, then held a two-stage exam (exam Exam I and II). Good exam exam I and II consists of multiple choice questions. Since the year 2010 exam only multiple-choice totaling 30 items. Exam is a collection of items from 10 taught training eye. However exam used both for training participants from year to year, there is no obvious difference, and the depth of material less prone to change towards improvement, construct validity exam is low, grain exams from year to year does not change either the test I and test II, use the same matter. Exam more dominant cognitive memory level. It's never complained of by the training participants who are elderly.

However, the rate stood at good value quite a lot, because the test results only to see the level of understanding of the material. Based on this scoring system the percentage of graduation of Training in Bapelkes Cikarang reached $100 \%$. The scoring system is based on information from 2017 training managers, all participants who participated in the training were declared to have passed so that they were entitled to get a certificate as the Hajj Pilgrimage Health Examination Team at the Puskesmas Level. This is evident from the results of tests that are performed before and after the training, where the highest value of the pre-test of 80.00 , the lowest average of 26.00 with a standard deviation of 56.17 and 15.9. While the post-highest test score 93.00, the low of 66.00 with an average of 84.67 and a standard deviation of 8.9. From the table lists the value of pre and post-test shows that the number of participants has increased the value by 28 participants, the number of participants has not changed is 2 people (both pre-test and post-test value is 80 ). No participants experienced a decline in value, the percentage increase in the value reached $93.33 \%$. From this learning result it can be concluded that the training reaches the target with the quality predicate achieved.

This study is in line with the results of research conducted, by $\mathrm{Wu}$, Roychowdhury, and Khan titled "Evaluating the impact of the healthcare provider training to improve tuberculosis management: a systematic review of methods and outcome indicators use" states that in order to evaluate the knowledge of participants of the training is done by using pre- and post-training tests. Further explained that this method is also most suitable for testing factual knowledge retention, improved quality of service and the application of diagnostic standards and treatment guidelines after the implementation of the training (Wu, Shishi, Roychowdhury, Imara, Khan, 2010).

\section{Evaluation Work Behavior}

Results training, participants are expected to have the ability to apply the knowledge that can be used directly in the work and changes in behavior (attitude) and concern for the rate of change and continuity. Workplace behavior is also focused on cooperation of factors which include how to socialize with friends and superiors, willing and able to work together, to accept and give advice, and does not impose the will.

To reveal the above, the questionnaire was given to the Head of the Puskesmas as the supervisor of the training participants at his workplace. Chief academic health centers to provide an assessment of the performance of alumni who became the staff at work. From the results of a questionnaire consisting of 23 items of questions, it was revealed that the application of the results of the training is generally included in both categories.

Focus on evaluation at the stage of work(behaviorbehavior) is on aspects: (a) application of knowledge; (b) attitude and loyalty; and (c) level of cooperation.

\section{a) Work behavior on aspects of the application of knowledge}

In detail, it can be explained that the application of learning outcomes in PPKJH training is based on the opinions of superiors, $2 \%$ in the category is always $53 \%$ in the frequent category, $45 \%$ in the category always, this means the use of knowledge obtained and directly related to duties and functions of alumni as health examiner officers Pilgrims of prospective pilgrims are well run in inspection activities.

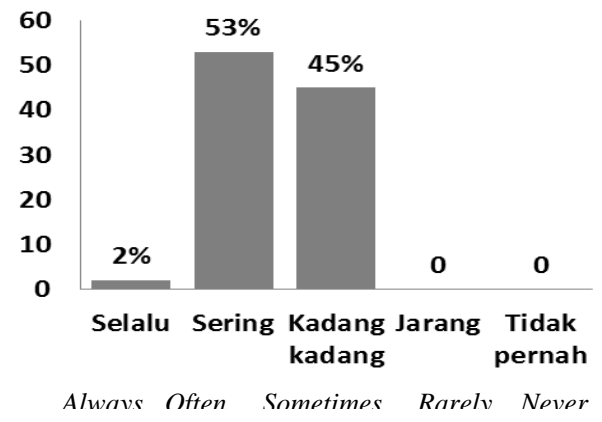

Fig 6. Participant behavior towards aspects of the application of knowledge

b. Work behavior on aspects of attitude and loyalty

To evaluate the application of aspects of changes in work behavior including good categories. This aspect includes: (a) discipline, (b) loyalty and perception of work, and (c) initiatives, namely the ability of alumni to provide suggestions and ideas for the progress of work units, and the application of new ideas in work. 
For more details, described in Figure 8 below:

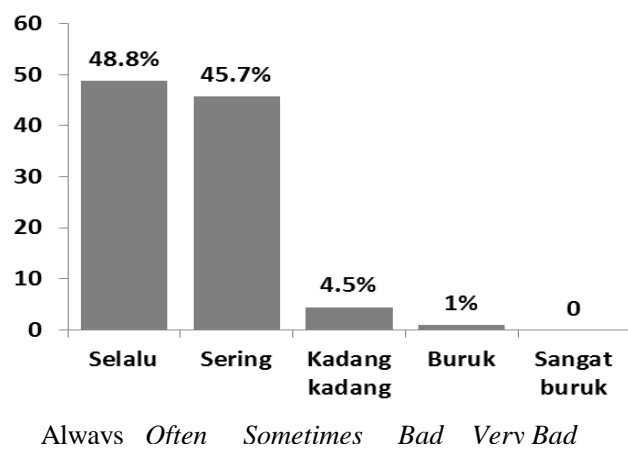

Fig 7. Participant behavior towards aspects of attitude and loyalty

Application in aspects of changes in work behavior (behavior) relating to the level of cooperation and initiatives based on the opinions of colleagues of alumni included in the good category. This is shown by the results of the questionnaire given to alumni coworkers. Where as many as $39 \%$ of coworkers say they can always work together, and $41.5 \%$ of their co-workers that alumni often carry out cooperation, but there are some colleagues who say $17 \%$ of the theme is in the category sometimes even $2.5 \%$ who said that they rarely worked together after participating in PPKJH training. This can be seen in the following diagram:

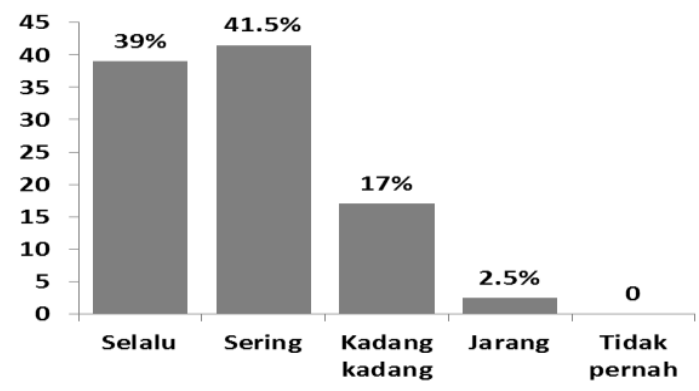

Always Often Sometimes Rarely Never

Fig . Partıcipant behavior towards aspects of cooperation

\section{CONCLUSION}

In general, the implementation of training at Bapelkes Cikarang for hajj pilgrims health examiners was in a good category. Specifically the conclusion of the results of the training evaluation is as follows:

Evaluation Reactions to Training Activity. Based on the reactions or responses of participants on the implementation of training programs conducted for 6 days in accordance with the amount of material (eye training) is given. For components that are associated with the flow of materials to the needs of the work unit, then there is a material that is still not applicable for participants who are not administrative personnel. Furthermore, Widyaiswara's performance in general is quite good and meets the standards, but there are some findings that need to be considered by the organizers, namely the teaching burden for each widyaiswara is still rather lame because there are widyaiswara who have to deliver more than one subject. Then in terms of the adequacy of learning facilities and infrastructure, it is sufficient to meet learning, where each study room is equipped with an LCD, stationery, white board, flipchart paper, sound system and

\section{c. Work behavior on aspects of cooperation} the standards of feasibility for conducting conducive

AC.

Evaluation of Learning Outcomes in training for health examiners for pilgrims, there are 9 training courses taught and supplemented with anti-corruption material. This is sufficient for the formation of discipline and character of civil servants as health examiners for pilgrims, however, knowledge related to the work unit of participants is only 5 eyes of training that are considered appropriate and suitable, namely health checks, health care and maintenance, health recording and reporting in Puskesmas, protection and control of individual health risk factors, and health development. For matters related to cognitive mastery of the material is already quite high. It can be seen from the results of the exam I and II.

Work Behavior Evaluation in the form of implementing learning outcomes obtained and changes caused are in a good category, this means that the use of knowledge acquired is almost entirely implemented. This happened because participants considered the material obtained at the training was considered familiar and had been carried out before they attended the training at Bapelkes Cikarang. Likewise the application or transfer of knowledge relating to changes in work behavior in aspects of cooperation, based on the opinions of colleagues included in the high category. This means that after participating in training, alumni are more likely to be open and ready to work together to help their colleagues at work. For behavioral changes in aspects of loyalty which include work habits, namely the level of attendance and timeliness, the average change is quite good, as well as alumni perceptions of work and institutions tend to be better.

Evaluation of results which is the impact that has been made on the work unit which includes the products produced, in the form of inspection administrative devices, shows improvements, more complete and quality. Likewise, the same results are shown in the technique of managing the health of the Hajj congregation, in the good category. This is based on observations of the appearance or performance of the examining officers in the examination room from preparation to completion.

\section{ACKNOWLEDGEMENTS}

This research work is supported by the Health Education and Training Agency.

\section{REFERENCES}

[1] Asfaw, AM, Argaw, MD and Bayissa, L. (2015) The Impact of Training and Development on Employee Performance and Effectiveness: A Case Study of Five District Administration Office, Bole Sub-City, Addis

[2] Crone, G. (2005). Evaluating of Executive Training, Canadian Government. In Executive Magazine. Retrieved from http://www.tbs-sct.gc.ca/eval/.html

[3] Daniel L. Stufflebeam \& Anthony J. Shinkfield. (1981). Evaluation Theory, Models \& Applications (Vol. 00). San Francisco: Jossey Bass

[4] Detyna, Beata, Detyna, Jerzy, Dudek-Kajewska, A. (2016). Evaluation of Training Programs by Medical Employees in A Chosen Hospital in Poland. Poland Managerial Economics, 17(2). Retrieved from http://dx.doi.org/10.7494/manage.2016.17.2.203

[5] Gall, Meredith, Joyce P. Gall, and Borg, W. (2007). Educational Reseach. New York, Pearson Publisher.

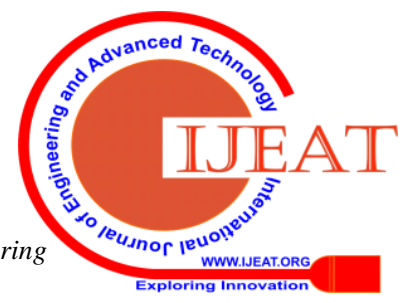


[6] Kirzpatrick, K. and. (2005). Evaluating Training Programs: The Four Levels, Third Edition. San Francisco: Berrett-Koehler Publishers Inc.

[7] Neeraj S. Borate, Gopalkrishna, Shiva Prasad HC, Sanjay L. Borate, A Case Study Approach for Evaluation of Employee Training Effectiveness and Development Program, The International Journal Of Business \& Management (ISSN 2321 - 8916) www.theijbm.com accessed December 23, 2017.

[8] Sugiyono. (2012). Metode Penelitian Pendidikan:Pendekatan kualitatif,kualitatis, dan R\&D. Bandung: Penerbit Alfabeta,bandung.

[9] Shahrooz Farjad, The Evaluation Effectiveness of training courses in the University by Kirkpatrick Model (case study: Islamshahr university), 1877-0428 (C) 2012 Published by Elsevier Ltd. le online atwww.sciencedirect.com, accessed December 15, 2017.

[10] Thoha, M. (2005). Civil Service Management in Indonesia. Jakarta: Kencana Prenada MediaGroup.

[11] Wu, Shishi, Roychowdhury, Imara, Khan, M. (2010). Evaluating the impact of the healthcare provider of management training to improve tuberculosis: a systematic review of methods and outcome indicators use. International Journal of Infectious Diseases. Retrieved from www.elsevier.com/locate/ijid

\section{AUTHORS PROFILE}

I am Lukman Ruskanda, affiliated with Balai Latihan Kerja Kesehatan Jakarta, Indonesia for further details contact me at lukman.ruskanda@gmail.com.

My name is Zulfiati Syahrial, working as Profesor at Universitas Negeri Jakarta, my area of interest is training.

I am Atwi Suparman, currently working as Profesor at Universitas Terbuka Jakarta.my area of interest is trainings and recruitment. 